\title{
P32 - Food anaphylaxis experience in children in Brussels
}

\author{
Anna-Maria Charatsi, Sandra Mulier, Gloria Aversano, Georges Casimir \\ From 3rd Pediatric Allergy and Asthma Meeting (PAAM) \\ Athens, Greece. 17-19 October 2013
}

\section{Introduction}

Anaphylaxis is a potentially life-threatening condition. There are limited data concerning etiology and clinical characteristics in pediatric patients.

\section{Aim}

To investigate the distribution of allergens, clinical characteristics and treatment of food anaphylaxis in a pediatric population in Brussels, Belgium.

\section{Method}

We conducted a retrospective study of 153 cases of food anaphylaxis. The patients were all referred to the department of pediatric allergology in Queen Fabiola's Children Hospital from January 2008 to December 2012.

\section{Results}

Age at the time of anaphylactic reaction ranges from 1 month to 15 years (median age 37 months), with 71 patients younger than 3 years $(46.4 \%)$. There is a male predominance representing $58.5 \%$ of the cases. The most commonly involved allergens are: peanut $(31 / 153,20.3 \%)$, tree nuts $(31 / 153,20.2 \%)$, cow's milk $(26 / 153,17 \%)$, eggs $(24 / 153,15.7 \%)$, fish $(9 / 153,5.8 \%)$ and shellfish $(8 / 153$, $5.2 \%)$. Reported symptoms are cutaneous (136/153, $88.9 \%)$, respiratory $(98 / 153,64 \%)$, gastrointestinal $(90 / 153$, $58.8 \%$ ) and neurological (53/153, 34.6\%). 97 reactions were severe with Sampson's scores 4-5, representing $63.4 \%$ of our cases. Most of the children were treated with antihistaminic medication $(91 / 153,59.5 \%)$, corticoids $(43 / 153$, $28.1 \%)$, beta2-mimetics $(32 / 153,20.9 \%)$ and adrenaline $(18 / 153,11.8 \%)$. Only $17.7 \%$ of the patients used their anaphylactic emergency kit already prescribed. Hospitalization was decided in 20 cases (13.1\%).

Queen Fabiola Children's Hospital, Brussels, Belgium

\section{Conclusion}

Food anaphylaxis occurred before 3 years old in almost half of the cases. Incriminated foods allergens are peanut, tree nuts, cow's milk, eggs, fish and shellfish. In $11.1 \%$ of the cases cutaneous symptoms were absent. Adrenaline was administrated in only $11.8 \%$ of the cases and $13.1 \%$ of patients were admitted to hospital. These results highlight the fact that food anaphylaxis is not treated as recommended. Education information needs to be tailored to parents and we need to stress out that adrenaline remains the primary treatment.

Published: 28 February 2014

doi:10.1186/2045-7022-4-S1-P87

Cite this article as: Charatsi et al:: P32 - Food anaphylaxis experience in children in Brussels. Clinical and Translational Allergy 2014 4(Suppl 1):P87.

Submit your next manuscript to BioMed Central and take full advantage of:

- Convenient online submission

- Thorough peer review

- No space constraints or color figure charges

- Immediate publication on acceptance

- Inclusion in PubMed, CAS, Scopus and Google Scholar

- Research which is freely available for redistribution 